\title{
A origem da vida - afinal, ¿as bactérias deram origem à vida?
}

\section{Dr. Fabiano de Abreu Agrela Rodrigues ${ }^{1}$}

deabreu.fabiano@gmail.com

\section{RESUMO}

São muitas as teorias que explicam a origem da vida. Uma delas assegura que organismos vivos viveram em simbiose para criar as células eucarióticas. Bactérias e arqueas se associaram e evoluíram em ambientes onde só se pensava ser possível a existência de eucariotos. Este artigo é com base em pesquisas para detalhar de forma resumida quem deu origem à vida.

Palavras-chave: origem da vida; bacterias; células

\footnotetext{
${ }^{1} \mathrm{PhD}$, neurocientista, mestre em psicanálise, biólogo, historiador, antropólogo, com formações também em neuropsicologia, neurolinguística, neuroplasticidade, inteligência artificial, neurociência aplicada à aprendizagem, filosofia, jornalismo, programação em python e formação profissional em nutrição clínica Diretor do Centro de Pesquisas e Análises Heráclito; Chefe do Departamento de Ciências e Tecnologia da Logos University International e da City University; Membro da SFN - Society for Neuroscience, Membro Redilat.
} 


\title{
The origin of life - After all, did bacteria give rise to life?
}

\begin{abstract}
There are many theories that explain the origin of life. One assures that living organisms lived in symbiosis to create eukaryotic cells. Bacteria and archaea have been associated and evolved in environments where only eukaryotes were thought to be possible. This article is based on research to briefly detail who gave rise to life
\end{abstract}

Keywords: origin of life; bacteria; cells

Artículo recibido: 02 enero 2022 Aceptado para publicación: 28 enero 2022 Correspondencia: deabreu.fabiano@gmail.com Conflictos de Interés: Ninguna que declarar 


\section{INTRODUÇÃO}

A Terra nasceu há 4,5 bilhões de anos, com o restante do Sistema Solar. As evidências fósseis das bactérias mais antigas datam de 3,5 bilhões de anos e a primeira significativa elevação do nível de oxigênio nos oceanos e na atmosfera só ocorreu muito depois, há 2 bilhões de anos; até à metade da história da vida no planeta, associado à origem da células modernas, ou eucarióticas: as células de que são feitos todos os organismos maiores que uma bactéria.

A comunidade científica já provou que os primeiros seres vivos do planeta foram as bactérias e as arqueas, organismos chamados de procariontes e formados por células mais simples, ou seja, não têm núcleos ou outras estruturas celulares, nem mitocôndrias. Têm capacidade limitada de produzir energia e podem viver em ambientes extremos e sem a presença de oxigênio. Então, se sabe, que organismos vivos mais complexos, seres humanos, animais, plantas, fungos e as algas, nasceram de células com núcleos, os eucariontes, que esbanjam energia.

A diferença entre os procariontes e os eucariontes está na produção de energia. As células dos eucariontes podem aumentar ou diminuir o número de mitocôndrias de acordo com a demanda de energia sem precisar aumentar o tamanho das células como os procariontes precisam.

A relação entre o grande evento de oxidação e a origem das células modernas é uma proposta de Lynn Margulis e outros pesquisadores, nos anos 1960, quando sugeriram que as mitocôndrias e nossas células procedem de antigas bactérias de vida livre. A bióloga Margulis achava que o aumento de oxigênio há 2 bilhões de anos foi precisamente o que levou outras células a ‘engolirem' aquela primitiva bactéria comedora de oxigênio, dando lugar à célula moderna.

\section{ENDOSSIMBIOSE}

Lynn Margulis foi a primeira pesquisadora a propor que as nossas mitocôndrias e os cloroplastos das plantas teriam se originado a partir de eventos de endossimbiose distintos, que ocorreram no início da evolução das células eucarióticas. As primeiras bactérias vivas surgiram provavelmente na Terra por volta de 3,5 bilhões de anos. Estas eram simples, com uma única camada lipídica, heterotróficas e anaeróbicas. A origem da célula eucariótica é mais controversa e deve ter envolvido, inclusive, eventos 
de endossimbiose. Uma das hipóteses que explicariam o surgimento das mitocôndrias envolve a associação de proteobactérias e arqueas.

Entretanto, a associação de uma arquea com uma bactéria invasora pode ter sido benéfico para as duas, pois a arquea poderia sobreviver na presença de oxigênio, normalmente tóxico para ela, enquanto a bactéria usufruiria do metano produzido em excesso pela sua hospedeira. Em seus estudos a pesquisadora argumentou que existem diversas evidências moleculares que corroboram que esse evento ocorreu de fato. Inclusive, nos dias de hoje diversos casos de procariotos endossimbiontes tem sido relatados em células de protozoários, animais e plantas.

Em “The Origin of Eukaryotic Cells" (1970), Margulis argumentou que as mitocôndrias são corpos retorcidos que geram a energia requerida para o metabolismo, e se parecem muito com bactérias. Essa similaridade sempre despertou a atenção dos cientistas desde a descoberta da mitocôndria no final dos anos 1800. Alguns até sugeriram que a mitocôndria se originou de uma bactéria que vivia em simbiose permanente dentro de células de animais e plantas. Havia exemplos paralelos em todas as células vegetais. As células de plantas e algas têm um segundo conjunto de organelas que elas utilizam para executar a fotossíntese.

Conhecidas como cloroplastos, elas capturam energia que recebem do sol. A energia conduz reações bioquímicas incluindo a combinação de água e dióxido de carbono para produção de matéria orgânica. Os cloroplastos, como as mitocôndrias, possuem grande semelhança com as bactérias e cientistas se convenceram de que ambos evoluíram de bactérias simbiontes - que descenderam de, especificamente, cianobactérias, pequenos organismos aproveitadores de luz que abundam em oceanos e água doce. Apesar do ceticismo da maioria dos pesquisadores, Margulis sempre manteve que as simbioses antigas ajudaram a formar células nucleadas.

\section{BACTÉRIAS DE VIDA LIVRE}

Estudiosos de institutos de pesquisa da Alemanha, Estados Unidos, França, Austrália e Nova Zelândia conduziram um experimento envolvendo bactérias de "vida livre" organismos unicelulares que vivem sozinhos na natureza - que mostra que a "ecologia" pode ser o elo perdido responsável pela centelha de vida.

O estudo mostra que a bactéria usada se reproduz por um processo chamado fissão binária: basicamente se dividem em duas metades idênticas. No entanto, quando a equipe 
forçou algo chamado "andaime ecológico" em grandes grupos de bactérias, eles encontraram um comportamento evolutivo semelhante ao exibido por grupos de espécies multicelulares.

Os pesquisadores relataram que ao forçar as bactérias nômades em grupos, elas exibiam um comportamento que colocava o bem-estar de todo o coletivo acima da sobrevivência de cada célula individual.

“Não apenas os grupos se tornaram mais bem-sucedidos, mas até desenvolveram características que sustentavam um programa de desenvolvimento que alimentava um ciclo de vida multicelular", ressalta a equipe.

Em essência, "produzimos uma receita ecológica que, se seguida, resultará na participação das entidades afetadas no processo de evolução por seleção natural, com o resultado sendo algum tipo de máquina darwiniana", sublinham.

Como escreveu Dennett, uma Máquina Darwin é uma construção pela qual uma entidade não viva - neste caso, um monte de células vivas agrupadas como uma comunidade que, por si só, não é um único organismo vivo - pode produzir um resultado com maior viabilidade do que seus conteúdos atualmente têm. Basicamente, as bactérias em grupos evoluíram para lidar melhor com seu ambiente do que aquelas que continuaram a viver por conta própria.

\section{TEORIA ASGARDIANA}

Outra teoria sobre a origem de todas as formas de vida complexa da Terra surgiu em 2015 quando cientistas escandinavos que rastreavam as profundezas dos oceanos descobriram as arqueas de Loki, batizadas em homenagem ao deus nórdico. Tinham apenas o DNA delas, pois era impossível isolar e criar no laboratório esses micróbios que vivem a mais de 3.000 metros de profundidade. Seus genes indicavam que essas arqueas eram os parentes mais próximos de todos os eucariotas. E que tinham genes essenciais para realizar funções básicas da vida eucariota, embora, em teoria, não os necessitassem.

Os pesquisadores argumentaram que todos os seres vivos que podem ser vistos a olho nu são feitos de células complexas, com organelas internas, chamadas eucariotas. Uma pessoa é um conjunto de 30 bilhões de células eucariotas que cooperam entre si com um objetivo comum. Na Terra há outros dois grandes domínios da vida: o das bactérias e o das arqueias. Estas últimas, mais primitivas, sem organelas internas, são o domínio mais misterioso e interessante. 
Desde então, foram descobertas outras arqueias similares - Thor, Odin, Heimdall, Hel que possuem genes eucariotas e foram agrupadas na família Asgard, o lar dos deuses nódicos. Segundo essa teoria, o ancestral dos eucariotas era uma arqueia similar à de Asgard. A bactéria, que até então era um organismo independente, transformou-se numa mitocôndria - uma organela que fornece energia ao seu hóspede. Essa hipótese coincide com a apresentada pela bióloga Lynn Margulis, como já mencionado no artigo. Naquela época a pesquisadora já afirmava que as mitocôndrias e os cloroplastos que ajudam as plantas a se alimentarem de luz nasceram por simbiose.

Como a primeira célula eucariótica emergiu ainda não está claro. Entre os vários modelos evolutivos concorrentes, os mais amplamente aceitos são os modelos simbiogênicos nos quais uma célula hospedeira arquea e um endossimbionte alfaproteobacteriano se fundiram para se tornar a primeira célula eucariótica.

\section{PARCERIA}

Uma hipótese surgida em 1988 defendida pelo microbiólogo americano Willian F.Martin e pelo bioquímico húngaro Niklos Müller, argumentava que a parceria começou entre uma bactéria que fazia respiração oxidativa, mas liberava hidrogênio, enquanto a arquea hospedeira usaria esse hidrogênio liberado pelo simbionte para poder reduzir o gás carbônico produzindo açúcares e metano. Com o tempo genes dessa bactéria simbionte acabaram migrando para a arquea hospedeira, originando nosso núcleo.

Com menos genes essa bactéria simbionte passou a fazer mais ATP do que precisava e esse excesso foi transportado para o hospedeiro, que precisaria produzir as proteínas extras dos genes que vieram do simbionte. Essa energia extra permitiu a construção de células mais complexas, com citoesqueletos, que as organelas membranosas dos eucariontes.

Outros pesquisadores propuseram que a ordem pode ter sido inversa: uma arquea que consumia moléculas orgânicas liberava elétrons e hidrogênio acabou se associando a uma bactéria que usava esses elétrons e esse hidrogênio. Segundo a teoria, independente da ordem dos fatores metabólicos o resultado seria o mesmo. A bactéria acabou sendo abrigada dentro da arquea e elas formaram os eucariontes.

\section{CONSIDERAÇÕES FINAIS}

As teorias revelam que a origem das células eucarióticas é consequência de uma colaboração entre bactérias e arqueas. A principal defensora da endossimbiose, a 
pesquisadora Lynn Margulis, afirmava que as grandes transições da evolução envolveram a fusão de dois ou mais seres vivos completamente diferentes. Segundo a teoria, a primeira relação de endossimbiose se estabeleceu pela associação entre uma arquea e uma alfa-proteobacteria, que foi interiorizada. A organela mitocôndria seria descendente dessa bactéria. As teorias endossimbióticas apontam as diferenças entre células procarióticas e eucarióticas, e explicam a origem dos eucariotos e suas mitocôndrias. Apesar do progresso recente, a origem da célula eucariótica permanece enigmática.

\section{REFERÊNCIAS}

MARGULIS, L. 1998. "The symbiotic planet: a new look at evolution"

MARGULIS, L. 1970. "The Origin of Eukaruotic Cells"

KONHAUSER, K. O. et al. 2011. "Aerobic bacterial pyrite oxidation and acid rock drainage during the Great Oxidation Event"

DENNETT, D. 1996. "Breaking the Spell, Freedom Evolves, and Darwin's Dangerous Idea"

LÓPEZ-GARCÍA, P. \& Moreira, D. 2015. "Open questions on the origin of eukaryotes" MARTIN, W. F., Garg, S. \& Zimorski, V. "Endosymbiotic theories for eukaryote origin" 